\title{
The Role of Work Environment and Work Motivation In Increasing Employee Performance
}

\author{
Suwarsito \\ Universitas Bina Sarana Informatika \\ e-mail: suwarsito.swr@bsi.ac.id

\begin{tabular}{ccc}
\hline Diterima & Direvisi & Disetujui \\
$21-02-2020$ & $10-03-2020$ & $14-03-2020$ \\
\hline
\end{tabular}

\begin{abstract}
The success of an organization resides on the employees' performance. It is necessary for the institutions or organizations to enhance the human resources. Giving work motivation and creating comfortable working environment can be some factors that must be considered to increase the performance. This study aims to explain the influence of environment of work variables and motivation of work on the performance of Wahana Visi Indonesia (WVI) employees. The methods of data collection in this study used a survey method through a questionnaire. The results of this study show that the work environment significantly influences the work motivation of WVI's employees, the work environment significantly influences the performance of WVI's employees, and work environment and work motivation simultaneously have a significant effect on the performance of WVI's employees. The satisfaction of the motivation and the comfort of the work environment can stimulate employees to work better.
\end{abstract}

Keywords: work environment, work motivation, employee performance

\section{INTRODUCTION}

Employees in an organization are the most important assets in achieving organizational goals, where employees who are able to produce good performance can contribute greatly in carrying out the activities of an organization. In enhancing the performance of employees, an organization must have a good a strategy and also create professional and good management. In order to achieve this goal, all available resources in the company must be involved.

Human resources needed at this time are human resources who have good performance, potential and loyalty to the company, so that employees are able to describe the vision and mission that has been mutually agreed in order to achieve company goals.

Performance is one of the most potential things that every worker must have to carry out every task and responsibility that are given by the company to the employees. With good performance, every worker can solve all company expenses effectively and efficiently, so the problems that occur in the company can be resolved properly. Performance of the employees or workers depends on the combination of efforts, ability and opportunity that is achieved by the employees. It means that performance is the output of the employees that are working for a certain period of time and the emphasis is on the work done by the employee within a certain time period. For motivating employees, every company usually evaluates the performance of its employees.

Motivation is an encouragement so that workers can work according to what is expected by the company. Providing motivation to employees can affect company activities in increasing work productivity. The growth of motivation in employees can improve employee work performance so that company goals can be achieved.

Work motivation in a company aims to encourage workers to be more active in conducting their work to achieve optimal goals and results. Implementation of work motivation focuses on the human factor in carrying out activities or jobs. In this case the role of a leader is needed to motivate its employees. With high work demands, work motivation must be maintained. it must also be supported by conditions that support the work environment. Providing motivation to employees can affect company activities in increasing work productivity. The growth of motivation in employees can improve employee morale. Conversely, if an employee is not motivated, his morale will also decrease. Work motivation is also influenced by the work environment.

The work environment according to Walgito (2000:37) consists of: (a) Physical environment and natural environment, for example buildings, spatial planning, work requirements, facilities / infrastructure; (b) Social environment, consisting of company policy, leadership style, interpersonal interaction. The social environment is a condition of individuals and society where in the environment there is an interaction between individuals with one another.

WVI is a non-government institution which is engaged in humanity and has carried out its activities both in regions within the country and abroad. As an institution, WVI strives to provide the best service to the community both in the fields 
of counseling, education and so on. Based on interviews with the human resources officer, there are still some workers who come late to work and late completing their work. The problems above can occur because employees are bored working, the work environment is less conducive and lack of motivation to work or can also be caused by other factors. The objectives of the research is to analyze whether environment of work and motivation of work have a significant effect on the performance of employee.

\section{Work Environment}

According to Nitisemito (2004:65), the work environment is something existing around employees and can affect themselves in doing and completing the tasks that are charged. Sedarmayanti (2001:21) broadly divides the work environment into two, non-physical work environment and physical work environment.

Wursanto (2009:269) calls a non-physical environment of work as a psychic environment of work defined as the things concerning the psychic aspects of the environment of work. This environment of work cannot directly be captured by the human senses, but its existence can be felt. So, non-physical work environment can be defined as a work environment that can only be captured by feelings. Based on the opinions and descriptions, it can also be said that the non-physical work environment is a work situation that cannot be captured by the five human senses. Comfort and security as workers, the relationship between workers and their boss and coworkers can also be classified as non-physical environment (Hidayati :2019)

However, this non-physical work environment can be felt by workers through the relationships between workers and their superiors. This non-physical work environment is no less important than the physical work environment. Employee morale is greatly influenced by nonphysical work environment conditions, such as relationships with fellow employees and with their leaders. If an employee's relationship with other employees and with the leader runs very well it will be able to make employees feel more comfortable in their work environment. That way employee morale will increase and performance will also increase.

The conditions and atmosphere of a good work environment will be created by a good and correct organization arrangement as said by Sarwoto (1991:131) that a good working atmosphere is generated, especially in wellorganized organizations, while a poor working atmosphere is often caused by organizations that are not well-structured. From this opinion it can be explained that the creation of a working atmosphere is strongly influenced by the existing organizational structure within the organization.

There are 5 aspects of non-physical work environment that can affect employee behavior such as:

1. Work structure, i.e. the extent to which the work given to him has a good work and organizational structure

2. Work responsibilities, i.e. the extent to which workers feel that work understands their responsibilities and is responsible for their actions.

3. Support and attention of leaders, the condition where employees feel that the leaders often provide direction, confidence, attention and respect for them.

4. Cooperation between groups, the extent to which employees feel there is good cooperation between existing work groups.

5. Smooth communication, the situation where employees feel that there is smooth, open and good communication, both between coworkers or with the leaders.

\section{Work motivation}

According to Manullang (2006:150), motivation is the granting of enthusiasm to work for employees. By providing motivation it is intended to provide stimulant power to the employee concerned so that the employee works with all his efforts.

Motivation is often also interpreted as a factor driving a person's behavior. According to Robbins (2008:222) motivation defines it as a process explaining the direction, intensity and perseverance of an individual to gain their goals. Based on this opinion it can be concluded that; (1) Work motivation is an urgent part in an organization that serves as a tool for achieving the goals or objectives to be achieved, (2) Work motivation contains two main goals in individuals, to meet personal needs or desires and organizational goals, and ( 3) Work motivation given to someone is only effective when within someone has confidence or conviction to move forward and succeed in the organization.

\section{Intrinsic Motivation}

Intrinsic motivation is comes from feeling satisfied in carrying out the work. It is a direct part of the work content. Therefore, according to Siagian (2004: 139) intrinsic motivation comes from within. The value of intrinsic work is related to the work itself. The intrinsic value of work includes an interest in work, learning new things, being challenged at work, making important contributions, making full use of work potential, autonomy, responsibility and creativity. Intrinsic motivation exists for positions of challenge and interest in work. 
Extrinsic Motivation

Rewards received by someone after doing work are related to intrinsic motivation. These rewards can be 4 promotions such as salaries, personal relationships, benefits and wages, this extrinsic motivation comes from outside of a person. Manullang (2001: 119) states that if the company gives inapropriate wages, working conditions, work safety or benefits, it will be difficult to attract good employees, and turnover, complaints will absenteeism. Motivation is not something that stands alone, but there are several factors that affect it. According to Arep (2003: 51) there are nine motivational factors, of which the nine can be summarized in six factors outline, namely:

1. Factors of human needs

a. Basic Needs (Economical)

The basic needs referred here are the needs for food, clothing, and housing which are commonly referred to as primary needs. To meet these basic needs, someone will work hard by deploying all their abilities, because the need for food, clothing, and housing is the most basic need that must be fulfilled.

b. Need for Safety (Psychological)

Included in the category of psychological needs here include the need for status, recognition, appreciation, and others. According to Arep (2003: 61 ), the desire of employees to achieve a certain status or to become a "figure", not only means that employees must have more opportunities to achieve progress, but also must be willing to accept more obligations. This means that the motivation to reach the coveted status will be strongly attached to him. c. Social Needs

One way to convince employees to feel at work is to ensure that they have many partners in the organization. Employees in an organization need to interact with fellow employees and with fellow supervisors and foster recognition of their work performance.

\section{Compensation Factor}

Compensation is necessary for workers, because compensation reflects the value of the work of the employee. In the case of salary provision, several factors must be considered, including:

a. The meaning of salary for employees.

For an employee salary has a deep meaning, something that can affect the level of life of the employee concerned with his family.

b. Basic salary giving

There are some basics in salary giving. One of them is work performance that is salary is based on the amount or value of goods sold or produced.

3. Communication Factors

According to Arep (2003:81), smooth communication is open communication where information flows freely from top to bottom or vice versa. In an organization communication needs to be well-established between superiors and subordinates or fellow subordinates, because with smooth communication the communication flow will run smoothly as well and there will be no miscommunication that will result in confusion in carrying out work in the organization. With smooth communication organizational policies will be more easily understood.

4. Leadership Factors

According to Arep (2003:93), leadership is the ability of an individual to master or influence other people or different communities towards a certain achievement. In achieving its goals to be able to master or influence and motivate others, in the application of human resource management, several leadership styles are used, including:

a. Democratic Leadership, emphasizes the ability to create morals and trust.

b. Dictatorial or Autocratic Leadership, emphasizes the ability to force.

c. Paternalistic Leadership, the form between the democratic and dictatorial styles above.

d. Free Rain Leadership, which is one of the leadership styles that $100 \%$ fully surrender all policies in the management of human resource to their subordinates by only sticking to the basic provisions.

5. Training Factors

Training is a means to improve the ability of employees in an organization. To further improve the quality of human resources, every organization needs to carry out education and training for its employees, both held inside and outside the organization. According to Arep (2003:108), training is a kind of effort to enhance human resources, especially in terms of abilities, knowledge, attitudes and expertise.

The benefits of training for employees are:

a. To increase motivation.

b. To increase knowledge, abilities, and skills in carrying out daily tasks.

c. To increase self-esteem and eliminate inferiority.

d. To streamline the implementation of tasks.

e. To cultivate a positive attitude towards the organization.

f. To increase morale and passion for work.

g. To enhance awareness of the organization.

h. Increase mutual respect between employees.

i. Provide encouragement for employees to produce the best.

j. Provide encouragement for employees to provide the best service.

6. Achievement Factors

The assessment of employee work conditions for the organization is a means for developing human resources. Whereas for 
employee performance appraisal can spur work morale, in order to improve further performance. Because the assessment of this achievement will feel that their work is recognized by the organization and then raises hopes for obtaining compensation from the organization. This is a source of work motivation that greatly affects employee performance.

\section{Employee performance}

Ezeanyim (2019:43) defines performance as a function of someone's efforts, skills and in certain situations. Harsuko (2011: 50) defines performance as an element of recording HR work results from time to time so it is known to what extent HR work results and what improvements must be done so that in the future it is better. To achieve the company's goals and objectives, the organization is organized into smaller work units, with a clear division of labor, work system and work mechanism.

Employee performance decreases if one of these factors is reduced or absent. For example some employees have the ability to do their jobs and work hard, but the organization provides oldfashioned equipment. Performance problems are the results of work obtained by someone in conducting the duties and responsibilities assigned to employees. Performance includes the quality of output and awareness at work. There are three reasons related to why goal setting affects performance, namely:

1. Goal setting has a direct effect, which is to focus activities towards certain rather than others.

2. Due to the goals that have been received, people tend to direct efforts proportionately to the difficulty of the goals.

3. Difficult goals will produce perseverance compared to light goals.

The appraisal performance is a process or the way where organizations can evaluate or assess employee performance. This activity can enhance personnel decisions and can provide feedback to the employees about performance implementation.

The usefulness of the performance appraisal uses are as follows:

1. Improved performance achievements. Work implementation feedback is likely that employees, managers, and the personnel department can correct their activities to increase performance.

2. Compensations adjustment. Evaluation of performance helps the institutions or organizations to determine bonuses, wage increases, and other forms of compensation.

3. Placement decisions. Transfers, promotions, and demos are usually based on the employees past performance achievements or anticipations.
Promotion is often a form of appreciation for past work performance.

4. The need for training and development. In one hand, poor performance might indicate a need of training. On the other hand, achievements may reflect the potential that must be enhanced and developed.

5. Planning and carrier development. Feedback of performance directs employees career decisions, which are about specific career paths that must be examined.

6. Informational inaccuracies. Bad performance might indicate errors in information on human resource planning, job analysis, or other components. Relying on inaccurate information can lead to personnel decisions that are not taken properly.

7. Mistakes of work design errors. Bad performance might be a sign of error in job design. Performance appraisals help diagnose those errors.

8. Fair performance chances. Accurate appraisal of performance will guarantee that internal decisions of placement are taken without discrimination.

9. External challenges. Sometimes performance is influenced by factors outside the performance environment, such as family, health, financial condition, or other personal problems.

Rahahleh (2019:82) said that the performance appraisal was conducted to assess behavior of employee in an institution or organization that aims to see the level of employee performance and also to review the employee performance quality against organizational goals. If the performance does not meet the standards, then to develop a performance improvement plan. In performance appraisal, employees are not only assessed physically, but the implementation of the work as a whole involving various fields such as work ability, craft, discipline, work relations, or special matters according to the field and level of their work. According to Mangkunegara (2009:67), performance evaluation factors are as follows:

1. Quality of work, such as accuracy, appearance, and acceptance of the output.

2. The quantity of work, including the output volume and the contribution of supervision that is needed, including requiring advice, improvement or direction.

3. Knowledge, including employee knowledge of their work.

\section{Hypothesis}

$\mathrm{H}_{1}$ : The environment of work (X1) significantly influences the motivation of work of WVI employees (Y)

$\mathrm{H}_{2}$ : Motivation of work (X2) significantly effect on employee performance $(\mathrm{Y})$ 
$\mathrm{H}_{3}$ : Environment of work (X1) significantly affects the performance of WVI's employees.

$\mathrm{H}_{4}$ : Work environment and work motivation simultaneously have a significant effect on the performance of WVI's employees

\section{RESEARCH METHOD}

The method of research used here is an explanatory research with a quantitative approach. The number of samples used in this study was 57 employees of WVI employees. The sampling technique uses random sampling technique that is the sample is taken randomly.

Data analysis techniques used are:

a. Descriptive analysis. Descriptive analysis is needed on research variables. Based on these variables, analysis can be done to get information about many things.

b. Analysis of multiple linear regression. Analysis of multiple linear equation models is used to simultaneously regress between independent variables and dependent variables.

In this study the regression model used is:

$$
\text { Information: }
$$$$
\mathrm{Y}=\mathrm{a}+\mathrm{b}_{1} \mathrm{X}_{1}+\mathrm{b}_{2} \mathrm{X}_{2}+\mathrm{e}
$$

$$
\begin{array}{ll}
\mathrm{Y} & =\text { Performance of employee } \\
\mathrm{X}_{1} & =\text { Work Environment } \\
\mathrm{X}_{2} & =\text { Work Motivation } \\
\mathrm{a} & =\text { constant } \\
\mathrm{b} 1, \mathrm{~b} 2 & =\text { regression coefficient }
\end{array}
$$

c. F test. to test the influence of the independent variables on the dependent variable simultaneously.

d. T test. T test was carried out to check the significance of each independent variable partially

e. Path Analysis is a kind of multiple linear regressions. Path analysis uses analysis of regression to estimate the causality among variables.

This study tries to corroborate the previous reseach done by Onanda (2015) showing that motivation has significant impact on employee performance, and also the research conducted by Hidayati (2019) showing that employee performace has a significant effect on employee performance.

\section{RESULT AND DISCUSSION}

To analyze the significance and the influence between independent and dependent variables can be conducted in two ways, first by conducting the $\mathrm{F}$ test which aims to find out the regression coefficient magnitude or the significance level of the two independent variables on the dependent variable, the second way is by using $\mathrm{t}$ test that aims to see the partial regression coefficient of each variable bound to the variable free. From the calculation using SPPS 20, the following regression equation is obtained. From the calculation using SPSS, it shows that: Y $=3.764+0,832 \mathrm{X} 1+0,621 \mathrm{X} 2$

Based on the results of the equation, it can be explained as follows:

a. constant (a) $=3.764$, shows the amount of performance, if the motivation of the environment of work and work motivation is zero, then the amount of performance is 3.764 .

b. the coefficient of work environment recession (b1) is 0,832 , indicating the magnitude of the influence of the work environment on performance, the positive coefficient of regression indicates the environment work has a direct effect on performance, which means that any improvement in the work environment will lead to improved performance.

c. work motivation regression coefficient (b2) of 0,621 indicates the effect of work motivation on performance. A positive sign of the regression coefficient indicates work motivation has a direct effect on performance, which means that any increase in work motivation will lead to an increase in performance.

The correlation coefficient (R) of 0.782 shows a high relation between work environment and work motivation on performance of $78.2 \%$, this relationship can be categorized as strong, as it is known that a relationship is said to be perfect if the correlation coefficient reaches $100 \%$ or 1 (both with positive or negative number)

From the results of the analysis above, the coefficient of determination is 0.585 . It shows that the work environment and work motivation variables can explain variation or be able to contribute to the performance variable by $58.5 \%$, while the remaining $41.5 \%$ is caused by other variables not included in the study.

\section{Hypothesis Testing}

\section{Hypothesis Testing 1}

Environment of work (X1) has a significant effect on employee work motivation (Y). t-test results obtained significance value of $\mathrm{t}$ work environment of 0,000 is smaller than $\alpha 0.05(0.000$ $<0.05)$, so it is proven that the work environment variable (X1) has a significant effect on employee work motivation ( $\mathrm{Y})$. thus the first hypothesis is statistically accepted.

Hypothesis Test 2

Work motivation (X2) has a significant effect on employee performance (Y). The results of t-test analysis of work motivation by 0.000 are smaller than $\alpha 0.05(0.00<0.05)$, so it is proven that work motivation variable (X2) has a significant 
effect on employee performance (Y). Thus the second hypothesis is statistically accepted.

Hypothesis Test 4

Work environment (X1) and work motivation (X2) simultaneously have a significant effect on employee performance $(\mathrm{Y})$ using the $\mathrm{F}$ test. The $\mathrm{F}$ test result of 0.000 is smaller than $\alpha=$ $0.05(0.000<0.05)$, so work environment and work motivation simultaneously have a significant effect on employee performance, so the third hypothesis is statistically accepted.

Path Analysis

From the output of the regression analysis using SPSS, the regression equation is standardized as follows:

$$
\begin{array}{ll}
\mathrm{ZWM} & =0.621 \mathrm{ZWE} \\
\mathrm{R} 2 & =0.376 \\
\mathrm{ZEP} & =0.422 \mathrm{ZWE}+0.413 \mathrm{ZWM}^{2}=0.592
\end{array}
$$

So that:

$\mathrm{e} 1=\sqrt{ }(1-0.376)=0.632 \mathrm{e} 2=\sqrt{ }(1-0.594)=0.401$

So the analysis is as below:

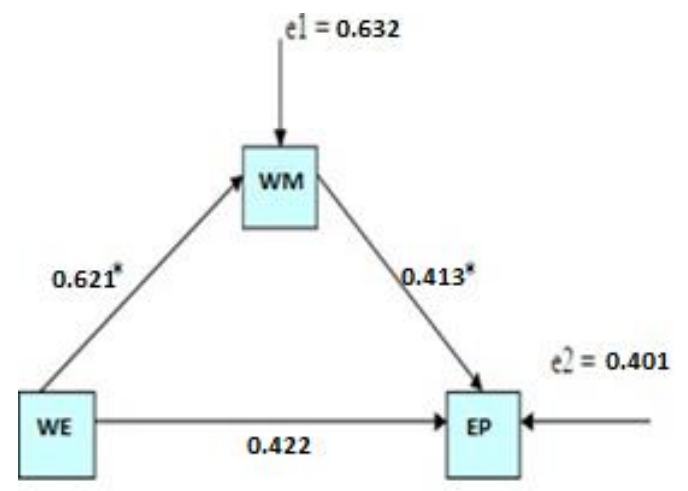

Figure 1: path analysis

Interpretation of the path analysis results can be carried out as follows:

- The direct influence of the work environment on employee performance

$=0.422$

- The indirect effect of the work environment on performance through work motivation $=(0.621 \mathrm{x}$ 0.413 )

$=0.26$

The total effect of the work environment on performance is $0.422+0.26=0.68$

\section{CONCLUSIONS}

1. The environment of work significantly affects WVI's employee work motivation

2. Motivation of work significantly affects the performance of WVI's employees.

3. The environment of work significantly affects the performance of WVI's employees.
4. Work environment and work motivation simultaneously have a significant effect on the work motivation of WVI's employees.

\section{REFERENCES}

Arep,Ishak dan Tanjung Hendri. (2003).Manajemen Motivasi. PT. Gramedia Widiasarana. Jakarta. pp 51,12

Ezeanyim (2019) The Impact of Job Satisfaction on Employee Performance in

Selected Public Enterprise in Awka, Anambra State : Global Journal of Management and Business Research (Vol. 19) p43

Hidayati.S, Karlina, Perrizade.B, Widayanti,M (2019) Effect of Work Discipline and Work Environment to Performance of EmployeeI : International Journal of Scientific and Research Publication p391

Mangkunegara.Anwar.Prabu; (2009) Manajemen Sumber Daya Manusia. 10 Perusahaan Bandung: Remaja Rosdakarya

Manullang. (2006) Dasar-Dasar Manajemen, edisi revisi. Ghalia Indonesia. Jakarta p150

Manullang. (2001). Manajemen Sumber Daya Manusia. Yogyakarta: BPFE p119

Nitisemito, Alex S. (2004), Manajemen Personalia, Ghalia Indonesia, Jakarta p65

Onanda, Belly.(2015) The Effects of Motivation on Job Performance A Case Study of KCB Coast Region: International Journal of Scientific and Research Publications (Vol.5)

Rahahleh, A, Hisam. (2019) The Impact of Performance Appraisal on Employee Performance in Banks Operating in the South of Jordan : International Journal of Human Resource Studies (Vol. 9), No. 4 p88

Robbins. Stephen. P; (2008).Perilaku Organisasi. PT. Indeks Kelompok Gramedia

Sarwoto (1991) Dasar-Dasar Organisasi Manajemen. Jakarta : Ghalia p131

Sedarmayanti. (2001). Sumber Daya Manusia dan Produktifitas Kerja. Mandar Maju. Bandung.

Siagian,Sondang P, 2004, Teori Motivasi Dan Aplikasinya,Bina Aksara Jakarta p139

Walgito, B. (2004). Psikologi Umum. Yogyakarta.p37

Wursanto, I., (2009). Dasar-Dasar Ilmu Organisasi, edisi dua. Yogyakarta: Andi p269 